\title{
A Descriptive Qualitative on Teachers' Strategies in Teaching Listening Comprehension
}

\author{
Rina Lukita Sari ${ }^{1}$, Rizky Gushendra ${ }^{2}$ \\ Universitas Islam Negeri Sultan Syarif Kasim Riau ${ }^{1}$, Universitas Islam Negeri Sultan \\ Syarif Kasim Riau ${ }^{2}$ \\ rinalukita.s@gmail.com ${ }^{1}$, rizky.gushendra@uin-suska.ac.id ${ }^{2}$
}

\begin{abstract}
The purpose of this research is to explore the implementation of teachers' strategies in teaching listening comprehension. There are three English teachers of SMPN 1 Rimba Melintang, who have been selected by purposeful sampling as the participants. However, A descriptive qualitative research was designed to presume the three aspects of teachers' strategies i.e. teachers' interpretation of teaching strategies, whilstteaching, and assessing students listening comprehension. In collecting data, the researchers conducted semi-structured interview in order to gain the deeper information from the participants. The results and analysis of the interviews found that the teachers' interpretation of strategies were interdependent and interrelated with other skills, which means to decide a strategy is very influential for the learning outcome. However, the decision of using different strategies might have different results. The second aspect, the audio-visual media enable the students to hear sounds and notice directly to the intended object, which followed by a group discussion and quizzes for question-answer sessions, that the students response immediately and spontaneously. Finally, the teacher assesses the results of student work by any particular drills, such as, summarizing the materials, noticing main ideas of the talks, doing presentation, and questions and answers.
\end{abstract}

Keywords: Teachers strategies, Listening Comprehension.

\section{INTRODUCTION}

Although an appropriate teaching strategy is necessary for students to improve their listening skill, there is a lack of research on it specifically. Western study of second language/foreign language listening comprehension strategies regards learning strategies as its theoretical framework, therefore many scholars consider listening comprehension strategies as learning strategies.
Chatom (1987, as cited in Bao, 2017) points out that learning strategy are techniques, approaches or deliberate actions that students take in order to facilitate learning and recall of both linguistic and content area information. Oxford (1990) defines language learning strategy as conscious step or behaviors used by language learners to enhance the acquisition, storage, retention, recall, and use of information. Ellis (1994) points out a strategy, which consists of mental or behavioral activity 


\section{Rina Lukita Sari, Rizky Gushendra - A Descriptive Qualitative on Teachers' Strategies in Teaching Listening Comprehension}

relates to some specific stage in the overall process of language acquisition or language use. Furthermore, Huang (2010) affirms that some English teachers are found less successful than others. Therefore, it is regarded more successful ones, they are required to be able to create interesting classes to have their students learning English since strategies have an undeniable influence toward students ${ }^{\text {ee }}$ achievement.

Listening is one of the essential skills to concern, because it is a basic skill to be developed. However, it needs great effort to enhance the learning outcome since it is considered a foreign language (Chen and Wei, 1998). According to Brown (2001), listening is an important skill through which language learners internalize linguistic information without which they cannot produce language. To make the teaching process become interesting, English teachers must understand the English language correctly as well as to speak English fluently. In other words, they have to be proficient in the target language that they can use English to teach the materials, to interact with students, to give instructions, corrections, and feedbacks on learner language. Therefore, students, as listeners, are enable to process information quickly from what the teacher says and explains. Otherwise, listening can be a stressful activity (Goh \& Taib, 2006, p. 222), which indicated by Song (2008), that listeners often do not handle listening tasks in an effective way and utilize the teachers' strategies successfully.

Furthermore, to raise the students ${ }^{\text {ee }}$ interest to learn English, the teachers should teach contextually that is by relating the topic to students' daily activities. In order to avoid a boring class, English teachers need to vary the students activities in teaching and learning process (Fajriah, Gani \& Samad, 2019, p.17). The use a various strategies when teaching listening, it can be developed students' motivation in comprehending the material. The implementation an appropriate method and technique by the teachers in a classroom will influence the outcome of the students. For example, by giving suitable listening materials, a proper classroom atmosphere, an appropriate teaching methods and meaningful exercises might help students to achieve good listening skills (Yusnida, Muslem \& Manan, 2017, p. 440). Moreover, the strategies used by teachers also need to be considered to improve students' comprehension; hence not all students understand what is said by the teachers. Therefore, the proficiency of an English teacher is not enough to make students understand in learning. However, the strategy used must be in accordance with the teaching context. To improve listening ability, the learners must use some strategies in listening skill. Goh (2000) emphasized the importance of these strategies by arguing that learners ${ }^{\text {ee }}$ awareness is related to effective learning in all learning contexts. Similarly, Abiola (2013) claims that there was an undeniable relationship between a teachers' strategy of teaching and students' attitude to the teaching and learning of the English language. This implies that expected performance of students, is based on teaching strategies. Osada (2004) and Sharma (2007), also indicated that one of the distinctive features differentiating successful listeners from unsuccessful ones is their use of listening comprehension strategies and they supported the idea that analyzing the role of these strategies in L2 listening helps listeners to approach the listening task more effectively. 
Based on previous research, this study emphasis on the learning strategies utilized by effective learners and suggested teachers that one of the first priorities in the designing of listening lessons should be instructed to students on how to approach listening, how to handle information that is not completely comprehensible (Mendelsohn, 1994, p. 134). However, the use of strategy is highly recommended in the learning process. If the students experience errors in acquiring information, the information will becomes vague and ambiguous. Moreover, in controlling students it takes a proper classroom management. Therefore, the effective strategies will help students and teachers interact well.

SMP Negeri 1 Rimba Melintang is one of Junior High School, which is located in regency Rokan Hilir. As an educational institution, this school provides a variety of subjects, one of which is English. Along with the times and the use of a curriculum that has been increased, the use of listening in learning English is very important. Besides listening is one of the skills, which is also a part of communication tools. Furthermore, in SMP Negeri 1 Rimba Melintang have a cumulative minimum standard (KKM) that must be achieved by the students. It is from 75 for all skill in English language. This is obtained from the source of the results after conducting interviews with the teachers. Based on the preliminary research, one of the problems is that there is no a language laboratory that is affordable for language learning. Moreover, it has found that some of students difficult in four language skills. In line with the problems, this research refers to the 2013 curriculum in which teachers must implement and adopt the effective strategy in teaching listening. It means, the teachers have their roles, not only to guide the students but also as facilitator. Therefore, the teaching and learning process can run well and smoothly. It expects a students' improvement in learning, such as students can respond interpersonal (socializing) conversations accurately, fluently and acceptably for interacting in the context of everyday life involving speech acts; asking and giving assurance, and expressing and responding to doubts.

Based on the problem depicted in the background, the researcher formulates some research questions as follows:

1) How do English teachers interpret on teaching strategies of listening comprension?

2) To what extent do English teachers implement on teaching strategies of listening comprension?

3) To what extent do English teachers assessing students' listening comprehension?

\section{LITERATURE REVIEW}

\section{a. The teaching strategies on listening comprehension}

Strategy is a way that everyone does to do something that is understood or planned. In learning language, the learners need technique, strategy, or tactic to obtain the success in learning process of language. Strategy plays its role as a key factor that influences the English language learning have an achievement (Ikeda \& Takeuchi, 2006). Each individual must be able to hear well so that good communication is established, one of them in listening comprehension. For that reason understanding in listening is very important. 
Moreover, in listening should be noted that before we teach strategies to learners, we should understand their specific areas of difficulty. We should also be aware of the strategies that they are already aware of. The result of a study conducted by (Graham, Santos and Vanderplank, 2008, and Holden, 2004) suggest that learners understand what they hear well if they are aware of the effective ways of using strategies to deal with various tasks. In defining the strategies, Oxford (1990) explains that the strategies are important for learning language because it is tool for active, self- directed involvement, which is essential for developing communicative competence.

Based on the definition above, it can be conclude that strategy is really needed in learning to listen. However, in the different categories and characteristics of students, of course the strategies used will also be different for each individual. As in the use of strategies, there are some students who in other contexts need strategies while in other contexts they do not. In addition, students interest how the way teachers teach is also very necessary. Thus, the students need the strategies to overcome the problems.

According to (Freeman, 2004 and Lin, 2006), listening comprehension by teachers strategies are techniques or activities that contribute directly to the comprehension and recall of listening input. In listening strategies that the teacher applies to students, it is to improve students' listening skills, especially in learning English. Therefore, students can be understood, to get information and communicate in the learning process. According to Vandergrift (1999), the development of strategy is significant for the training of listening and learners can guide and assess their own understanding and answers. Therefore, to get the comprehension of the students in listening skill they should had a technique to success in learning listening or made them easily in listening comprehension.

Furthermore, Rubin (1994) claims that listening strategies can be taught and done in comprehension improving. There are very many strategies that can be used in listening comprehension.

\section{b. Kinds of Teachers Strategies in Listening Comprehension}

Listening strategies can be classified into how the listener processes the input. There are two cognitive processes: bottom-up (datadriven) and top-down (conceptuallydriven). Wilson (2008, p.60-110) states that teaching listening strategies can be carried out in three stages, namely pre-listening, while-listening, and post-listening. Within these stages, there are two processes: bottom- up process and top-down process (Wong, 2005, p. 26). Those are teaching and learning of listening by focusing on identifying single words, phrases and sentences which called bottom-up processes; and the other by focusing on the main ideas or meaning called top-down processes. The two processes can be used together which is called interactive strategy (Shelton, 2004).

\section{1) Top-down Processing Strategy}

The term top-down processing came originally from computer science and carried the meaning of "knowledge driven" (Field, 
1999). This term is used in description of the cognitive processes of foreign language listening and foreign language reading. In Top-down processing, the learner draws upon background knowledge and expectations of what will follow next in the discourse and then infers what the intentions of the speaker may have been. Inference is an important part of the process, and it is important to note that the reader or listener, through the process of inferring meaning, may or may not correctly interpret the meaning of the written or spoken text (Rost, 2005).

Moreover, the top-down process refers to relating the text to prior knowledge by integrating it into existing and evoked schemata (Jin, 2002). "Through top-down processing, readers and listeners utilize real-world knowledge and refer to various types of schemata that help them predict what will follow in the discourse" (Jung, 2003, p. 563). Top-down strategies are listener-based; the listener taps into background knowledge of the topic, the situation or context, the type of text, and the language. Topdown processing strategy refers to predicting what the speaker says by the signal given (Jou, 2010).

In top-down processing strategy, the students guessing the meaning from the topic and also made summarize about the speaker said. This background knowledge activates a set of expectations that help the listener to interpret what is heard and anticipate what will come next. Topdown strategies include listening for the main idea, predicting, drawing inferences, and summarizing.

Furthermore, the listeners focus on main ideas or meaning the sentence, phrases, and single words in this strategy. There are some exercises, which involved in top-down listening, use key words to construct the schema of a discourse, construct plans and schema from elements of a discourse, infer the role of the participants in a situation, infer the topic of a discourse, infer the outcome of an event, infer the cause of effect of an event infer unstated detail of a situation, infer the sequence of a series of event, infer comparisons, distinguish between literal and figurative meanings, and distinguish between facts and opinions. Top-down strategies include: listening for the main idea, predicting, drawing inferences, and summarizing. An example: listening to a friend told a story about a terrible vacation in "Lawang Sewu" with a mutual friend. This kind of listening 
required the use of background knowledge in understanding the meaning of the message. Background knowledge consisted of context. Did you ever get your students to predict the content of a listening beforehand, maybe using information about the topic or situation, pictures, or key words?

\section{2) Bottom-Up processing strategy}

In bottom-up processing, known from computer science as a "data-driven" process (Field, 1999). The bottom-up processing involves constructing meaning from the smallest unit of the spoken language to the largest one in a linear mode (Nunan, 1998). Bottom-up strategies are text/speech based; the listener relies on the language in the message, that is, the combination of sounds, words, and grammar that creates meaning.

Moreover, Suwarni (2014) said that, bottom-up processing strategy is a process of understanding the meaning of sound by finding out the meaning of word, semantic content, and syntactic level. Thus, the learners attempt to understand a spoken discourse by decoding a number of sounds to form words. Next, words are linked to form phrases, which make up sentences. These sentences build a complete text, the meaning of which then constructed by the listeners.

In addition to the grammatical relationships, stress, rhythm and intonation also substantially contribute to this data driven processing (Van Duzer, 1997). Learners can be trained to perform this processing, for instance, by activities that require them to discriminate two sounds or distinguish rising and falling intonations. There are exercises that involve bottom-up listening; retain input while it is being processed, recognize word division, recognize key word in utterances, recognize key transition in a discourse, use knowledge of word order patterns to identify constituent in utterances, recognize grammatical relations between key element in sentences, recognize the function of word stress in sentences, and recognize the function of intonation in sentences.

Furthermore, bottom-up strategy the teacher focused on identifying single word, phrases, and sentences. Besides, the teacher also focused on identifying the sound because students are often wrong in the pronunciation and the writing of the spoken text which was heard. Here, the teacher gave students the correct pronunciation and writing 
when they have wrong pronunciation with the word that has played. Then, the teacher asked the difficult word to the students and asked to identify phrases (verb phrase, noun phrase, adjective phrase, etc.). After that, the teacher asked the students to know the purpose of oral text, which has heard. Bottom-up strategies includes; listening for specific details, recognizing cognates, and recognizing word-order patterns.

Example: listening to directions from a friend on how to get to his/her house. This kind of listening comprehension was achieved by dividing and decoding the sounds - bit by bit. The ability to separate the stream of speech into individual words became more important here, if we were to recognize, for example, the name of a street or instructions on how to take a particular bus. Understanding vocabulary and other specific parts of speech was also very important for this kind of listening.

\section{3) Interactive Processing Strategy}

As the development of language teaching, the listening strategies are now developing. The teacher or instructor combined the two listening strategies above to teach the students, which is called interactive processing.
According to Peterson (2001, as cited in Yaqin, 2013), interactive processing is the combination of top- down and bottom-up data.

In addition, the interactive process model (Park, 2004, as cited in Rahimi, 2012) shows how it takes both top-down processing coupled with bottom-up processing for comprehension to take place. In this strategies", the students are required to have brainstorming with other students or partner, such as, discussing vocabulary related to a topic, or invent a short dialogue relevant to functions such as giving directions or shopping. In the process, they base their information on their knowledge of life (top-down information) as they generate vocabulary and sentences (bottom-up data). Top-down and bottom-up processing act in a reciprocal way. The more basic the learner, the more likely it is that $\mathrm{s} / \mathrm{he}$ will rely most heavily upon bottom-up processing. In the early stages of language learning, it takes great concentration to decode the sounds of the language. The learner will need to expend great conscious effort, giving concentrated attention to the incoming stream of language, so much effort, in fact, that the learner may not have capability 
to focus on top-down processing.

The result is a more integrated attempt at processing. The learners are activating their previous knowledge. Also, according to Richards (1990, as cited in Yaqin, 2013) the success of listening strategies will depend on the combination of the both, Top-down and Bottom-up Processing. Thus, the combination of the two listening strategies will be very useful for the teacher to teach the Listening course.

\section{c. English Teachers Assessment of Student's in Listening Comprehension}

In the teaching and learning process of listening, there are some ways of assessing tasks and techniques in testing listening. There are two kinds of listening assessments, namely formative and summative assessments (Brown, 2004, p. 13, as cited in Yusnida, et.al., 2017). As Settiawan \& Hilmawan (2016) noted, formative assessment is given during the instruction or course while summative assessment is given typically after a semester or at the end of instruction or course. In this study, the extent of English teachers assess students" listening comprehension is focused to describe the type of formative assessments which are administered by teachers to their students.

The assessment of listening skills should have validity, reliability, authenticity and wash-back. Brown and Abeywickrama (2010, p. 30, as cited in Yusnida, et.al., 2017) state that, validity means to what degree assessment measures accurately what you want it to measure. Reliability means to what degree it is dependable. Authenticity means to what degree it is representative of real-life language use. Wash-back means to what degree it provides useful feedback for the learner and influences the teaching process.

Rost in Helgesen and Brown (2007, p. 19) outlines some listening assessment and testing techniques. They are as follows:

1) Discrete-item tests

$\checkmark$ Multiple choice questions following a listening test (responses scored right or wrong).

$\checkmark$ True-false format (responses scored right or wrong).

$\checkmark$ Open questions following presentation of a listening text (questions scored on a scale or correctness and completeness).

\section{2) Integrative tests}

Dictation, complete or partial (score based on supplying the correct missing words).

\section{3) Communicative tests}

Written communicative tasks involving listening (scored on the basis successful completion of a task, such as writing a complaint letter after heading a description problem).

\section{4) Interview tests}

$\checkmark$ Face to face performances with the teacher or another student (scored based on a checklist of items, such as appropriate response to questions, appropriate use of clarification questions).

$\checkmark$ Extended oral interview (scoring is keyed to a scale of native-like behaviors). 


\section{5) Self-assessment}

$\checkmark$ The learner rates self on given criteria, via questionnaire

$\checkmark$ The learner provides holistic assessment of their own abilities via oral or written journal entries

6) Portofolio assessment

$\checkmark$ The learner is observed and evaluated periodically throughout the course on behavior in tasks and other class activities: observations maybe audio or video-taped.

$\checkmark$ Portfolio may include any or all of the above types of objective and subjective measures.

\section{METHOD}

This research is a descriptive qualitative as a research design, since this purpose of the study to explore the teachers strategies in teaching listening comprehension at SMP Negeri 1 Rimba Melintang. According to Ary (2010, p. 419) Qualitative research investigates the quality of relationships, activities, situations, and materials. It focuses on understanding the context and attempts to explain the intentionality of behaviors. Furthermore, according to Ary (2010: 424-425), descriptive data in qualitative research is the qualitative inquirer deals with data that are in the form of quotes from documents, field notes, and interviews or excerpts from videotapes, audiotapes, or electronic communications are used to present the findings of the study. The data collected are the participant experiences and perspectives.

The participants of this research will be the teachers at SMP Negeri 1 Rimba Melintang. There are three English teachers will be taken as the participants in this research, it is called purposeful sampling. Because, the researcher wants to get depths understand about the central phenomenon. The semi-structured interview was selected to make the discussion which is focused on the main topic. In an interview, the researchers used the interview guideline to lead the interview questions, which was a list of questions or issues that were to be explored, that contains the strategy in teaching listening comprehension

\section{FINDINGS AND DISCUSSION}

To analyze the data that has been collected, it is uses a descriptive qualitative, which analyzed data based on phenomena by a discussion from existing theories or opinions. Qualitative research places more emphasis on understanding complex relationships between all that exists, and trying to build understanding that is expressed by readers through the description. Therefore, this research is descriptive qualitatively by means of data obtained from the informants described.

Furthermore, this section aims to generate further insights and interpretations of the finding within the contexts of research in teacher's strategies in teaching listening comprehension at Junior High School 1 Rimba Melintang, Rokan Hilir. The researcher finds some points that showed about the teacheres strategies in teaching listening comprehension. The discussion of the findings is presented based on one research question as follow: 


\section{a. How do English teachers interpret what listening strategies focusing at SMPN 1 Rimba Melintang?}

The first respondent, the teacher said the use of strategies in listening is important. This is important, because the respondent said that they have the interrelationships and interdependencies of each skill. It is mean, every each skills in English is related to another skills. Especially, in listening which has a related to speaking skill. According to Gao (2001, as cited in Nan, 2018) oral English proficiency of college students on the basis of understanding the inter-relationship between speaking and listening.

Furthermore, the teacher said that the purpose of the teacher uses a strategy so that students can understand the material being discussed. According to National Capital Language Resource Center 2004, listening strategies is a tool or activities that have contribute in input of listening comprehension for the students. For example, the material on that day was about descriptive text, and then the teacher explained to the students that was the purpose and forms of descriptive text. From this, students understand the content, forms, or depictions of animals, humans or plants that are contained in descriptive texts and students also understand the material.
The second respondent, he said that strategy is very important to apply to learning. On the viewpoint of the second respondent, the use of strategy is very influential in learning. Moreover, he said that the use of different strategies will produce different results. According to the respondent, a good strategy is one that exerts a little energy but the results are extraordinary. Oxford (1990) argues that the strategies are important for learning language because it is tool for active, self-directed involvement, which is essential for developing communicative competence. More advanced listeners use increasingly varied strategies than less advanced listeners (Murphy, 1987; Chin \& Li, 1998; Goh, 2002; Chao \& Chin, 2005). Furthermore, strategy plays its role as a key factor that influences the English language learning to achieve the goal (Ikeda \& Takeuchi, 2006).

The third respondent, the teacher uses strategies in listening is a way to develop ways in learning to listen. It is mean, if some students experience difficulties when learning in class, the teacher can use other types of strategies that can develop students-mindsets. Therefore, the students do not only focus on listening to learning, but also good strategies also support the learning process. 
In addition, the teacher wants that when teaching, her class does not become boring and saturating. The importance of using strategies is to be more efficient and besides that the teacher can also adjust the strategies needed for the subject matter. Oxford (1990, p.8) said that the students who are better placed in the listening comprehension due to the fact that they acquired effective learning strategies.

\section{b. To what extent do English teachers implement listening strategies at SMP Negeri 1 Rimba Melintang?}

This question about the implementation of teachers' strategies in teaching listening comprehension. It is about how the teachers teaches using strategies, what forms of strategy the teachers used, or the media used by the teachers in teaching listening. From the result, it can be interpreted that all English teachers in SMP N 1 Rimba Melintang use strategies in teaching listening as follow:

The first respondent, in this implementing, the teaching listening comprehension was taught by preparing the material and all of the instruments and speaker which must be used in the class, consisted of the media. In this step, the teacher prepares an Infocus or projector in the classroom for listening. The teacher used to apply audiovisual with projector, laptop, and speaker to teach listening comprehension in the class, then the teacher shows the video.
Wilson (2008, p. 40) states that there are several sources of listening materials. They include: teacher talk, student talk, guest speakers, textbook recordings i.e. talking books, tape recordings, television, video, DVD, radio and the internet.

In this case, the teacher uses audio-visual to teach listening to students. By using audio-visual, it means that there is media shown and it can help students' listening comprehension. Listening is very much an active process of selecting and interpreting information from auditory and visual clues (Richards, 2008).

The second respondent, in this implementing, because the teacher teaches in the 7th grade students' class, the teacher has matched the material according to the student's standards. Helgesen and Brown (2007, p.32-37) proposed some principles for teaching listening to beginning learners, one of them is aware the goal of the task, their said "In giving the material, the appropriate goal must be considered based on students. It means that the listening activity must be suited with the students' level, age, and needed.

This is the reason why teachers use audio-visual, because it enables the students to hear sounds and see directly the intended objects. Moreover, Solomon (2004, p. 349) promoted audio-visual segments can illustrate an event or a procedure that students feel as though they are actually there.

The third respondent, in
preparing pre-teaching, the
teacher activates students to


understand the audio or text that has been given, after that the teacher will provide training to practice their understanding of what they hear. McMullin (1992, p. 29) asserts that the essential components of a lesson plan are; warm- up/review, introduction to a new lesson, presentationintroducing new information, practice and apply the new language or information, and evaluation to assess how well they have grasped the lesson.

c. To what extent do English teachers assess students' listening comprehension at SMP Negeri 1 Rimba Melintang?

The feedback is in the form of an assessment given directly by the teacher. In this case, it is explained how the teacher gives grades or teacher techniques in taking grades in each student's work both at school and at home, then the types of assessments used by the teacher in listening be it in school exams, daily tests or daily assignments performed by students.

The first respondent, the teacher teaches in the class 8th grade students. In evaluating the students, listening skill was an important skill in learning English because the language is not only to be read, but also to be expressed and also responded to or listened to. Brown (2001, p.263) suggests that learning to listen and learning to respond. Furthermore, if students cannot understand their communication skills, or do not understand what is spoken, students will not be able to be responsive. Rost (2002) defined listening as a process of receiving what the speaker actually says, constructing and representing meaning, negotiating meaning with the speaker and responding, and creating meaning through involvement, imagination and empathy.

The second respondent, he explained that the good grades, can be a motivation for themselves, which means, if their grades are good it means that the attention and work of the school they are working on is successful and what they have learned is not in vain. Marzano (2000) stated that the most important purpose for grades was to provide feedback to students, if referencing for grading was content specific, letter grades and numerical scores would lead to an increase in students' performance. In addition, according Butler (1988), found that students receiving comments specifically tailored to their performance resulted in a significant increase in scores on a task. Students receiving only grades showed a significant decline in scores, as did a group that received both grades and comments.

\section{CONCLUSION}

From previous findings and discussions, it presents some conclusions about the teachers' strategies in teaching listening comprehension and assessing study feedback at SMP N 1 Rimba Melintang, Rokan Hilir, which are stated as follow:

- Although listening is not taught on a scheduled basis, the teachers still teaches listening in daily life. However, The opinions of the teachers regarding the interpretation of strategies in listening differ, that the strategies 
in listening were interdependent and interrelated with other skills.

- The implementation in listening has similarities. The teachers use various techniques and media such as; audio-visual to hear sounds and see directly the intended object, dictation, group discussion and quizes for question-answer sessions.

- The teachers' assessment in listening have different point of views. The teacher assesses their students by noticing accuracy in answering the missing text and thus, having group discussion, question-answer session, fill in the text and a homework. Moreover, the teacher assesses their work with the guidance contained in the worksheet.

\section{REFERENCES}

Ary, D., Jacobs, L. C., Sorensen, C. (Ed). (2010). Introduction to Research in Education: Eight Edition. USA: Wadsworth, Chengage Learning.

Bagheri, M. \& Karami, S. (2014). The Effect of Explicit Teaching of Listening Strategies and Gender on EFL Learners' IELT Performance. Journal of Language Teaching and Research, 1387-1392.

Bao, X. (2017). A Study on Listening Strategies Instructed by Teachers and Strategies Used by Students. International Journal of English Linguistics, 186-195.

Brown, H. D. (2001). Teaching by Principles: An Interactive Approach to Language Pedagogy. San Fransisco: Addison Wesley Longman.

Ching, A. \& Chang, S. (2008). Listening Strategies of L2
Learners With Varied Test Tasks. TESL CANADA JOURNAL, 1-26.

Creswell, J.W. (Ed.). (2012). Educational Research: Planning, Conducting And Evaluating Quantitative And Qualitative Research: $4^{\text {th }}$ Edition. Boston: Pearson Education.

Chomsky, N. (1965). Aspects of the Theory of Syntax. Cambridge: The MIT Press.

Chomsky, N. (1986). Knowledge of Language: Its Nature, Origin and Use. NY: Praeger.

Dulay H., Burt M., \& Krashen S. (1982). Language Two. New York: Oxford.

Ghoneim, N. M. M. (2013). The Listening Comprehension Strategies Used by College Students to Cope with the Aural Problems in EFL Classes: An Analytical Study. Canadian Center of Science and Education, 110-112.

Gilakjani, A. P. \& Ahmadi, M. R. (2011). A Study of Factors Affecting EFL Learners' English Listening Comprehension and the Strategies for Improvement. Journal of Language Teaching and Research, 977-988.

Gilakjani, A. P. \& Sabouri, N. B. (2016). Learners' Listening Comprehension Difficulties in English Language Learning: A Literature Review. English Language Teaching, 123-133.

Jin, K.-A. (2002). The Effect of Teaching Listening Strategies in the EFL Classroom. 988-999.

Kazemi, A. (2017). An Investigation into Listening Comprehension Strategies and the Relationship between Listening Comprehension Strategies and Overall Proficiency Level of Intermediate and Advanced 
Learners. Journal of Language Teaching and Research. 149-156.

Khan, I. U. \& Karim, A. (2014). Strategies for improving English language Listening Skill (The Case of Distract Bannu). Research on Humanities and Social Sciences, 37-48.

Lipnevich, A. A. (2008). Response to Assessment Feedback:The Effects of Grades, Praise, and Source of Information. Educational Testing Service, 1-28.

Lipnevich, A. A. \& Smith, J. K. (2009). Effects of Differential Feedback on Students' Examination Performance. Journal of Experimental Psychology: Applied, 319-333.

Richards, J. C. (2011). Exploring teacher competence in language teaching. The Language Teacher, 35(4), 1-7.

Watthajarukiat, T., Chatupote, M., \& Sukseemuang, P. (2012). An Investigation of English Listening Strategies Used by Thai Undergraduate Students in Public Universities in the South. 1-17.

Walker, N. (2014). Listening: The Most Difficult Skill To Teach. 167-175. 